\title{
National strategy for teacher training in new ICT use:
} The Ukrainian case

\author{
Valentina Kolos \\ International Research and Training Centre (UNESCO) of Information Technologies and \\ Systems, Kiev, Ukraine
}

\begin{abstract}
The paper presents the current state of teacher training in ICT use in the Ukraine. A short history of this process is described. National policy directions and actions are considered.
\end{abstract}

Keywords teacher training, in-service education, life-long learning, national policy

\section{SHORT HISTORY}

The first steps in the uses of telecommunications for education were made in the Ukraine in 1995 by a research group from the International Research and Training Centre (UNESCO) for Information Technologies and Systems (IR\&TC). Telematic-based learning received further development support due to a European Commission funded Copernicus Project: 'Flexible and distant learning through telematics networks: a case for teaching English, and communication and information technologies' (1995-1997).

At the same time (1996), due to the work of the Eurasia Foundation, the first Ukrainian telematic-based (e-mail based) course on internet basics was developed and implemented. This action may be considered as the beginning of teacher training on ICT activity in the Ukraine, because the course learning material and experience gained was used as a starting point for development of the WWW-based programme for teacher training that consists of two courses:

- Communication and information technologies (basic internet services) (Dovgiallo et al., 1997), and

- Distance course design and development (Dovgiallo et al., 1998).

The original version of this chapter was revised: The copyright line was incorrect. This has been corrected. The Erratum to this chapter is available at DOI: 10.1007/978-0-387-35615-0_52 
The next step in teacher training activity was concerned with involvement in multimedia uses in telematic-based learning. This activity was supported by the INCO Programme Project: 'Multimedia application for educational telematics network' (1998-1999). The framework for teacher training on multimedia telematic-based courseware design and development was elaborated in the IR\&TC (Kolos, 2001).

As we can see the first courses and correspondence programme for teacher training in telematics use were developed and elaborated within the scope of international co-operation, and accumulate the best experience and practice of the leading universities from participating countries (The Netherlands, United Kingdom, Bulgaria, Lithuania, Russia), without governmental structure participation and support.

\section{TEACHER TRAINING NATIONAL POLICY}

The quantity of students who are able and willing to study the use of distance technologies is now quite large and increases very quickly. So, the training of teachers is critical for distance learning technology dissemination, to ensure that the full potential of telematics is exploited for the benefit of citizens.

Unfortunately, modern ICT technologies are not now the focal point of traditional in-service teacher training.

Traditional universities all over the world have a major need for development of a new system of university education. In educational centres, in which the current experts are concentrated, the traditional universities have significant potential to become the centres of development of modern distance university courses. There are universities in the Ukraine that now have distance learning departments:

- the Institute of Investment Management (URL: http://www.kimi.kiev.ua/),

- the International Finances University (URL: http://iuf.ntu-kpi.kiev.ua/),

- the Ukrainian Academy of State Management (URL: http://www.uapadlc.org.ua).

Many Ukrainian educational organisations are trying to implement distance learning technologies and to develop correspondence departments, but few can satisfactorily resolve the teacher training issue. Today only four Ukrainian educational organisations have put into regular practice a teacher training curriculum on modern ICT:

1. IR\&TC (URL: http://boy.dlab.kiev.ua/PRJ/3kursa/first.html) - which provides telematic-based learning;

2. the Ukrainian Distance Education Centre (URL: http://udec.ntukpi.kiev.ua/) - which provides classroom-based learning; 
3. the Problem Laboratory for Distance Learning of Kharkiv Polytechnic University (http://users.kpi.kharkov.ua//re/) - which provides telematicbased learning;

4. the Ukrainian Academy of State Management (http://www.uapadlc.org.ua/) - which provides classroom-based learning.

Unfortunately the main drawback of the majority of projects from the point of view of teacher training in new ICT uses is the emphasis on technical and technological aspects at the expense of methodological, and pedagogical aspects.

National policy in the teacher training area is implemented through international projects (examples are described above) and a range of different funds and sponsorships (the Renaissance Foundation, and the Internet Access and Training Programme (IATP) is funded by the Bureau of Educational and Cultural Affairs of the U.S. and others), UNESCO contributions, university initiatives, and state actions.

The main vehicle for state policy in the information technologies area is the National Informatisation Programme which was adopted in 1998. It includes a section devoted to science and education informatisation. The section activities include:

1. The five year project - 'Means development for distance educational technology implementation for vocational training, retraining and lifelong learning' that were started in 2000.

2. The development and adoption of the conception of distance learning development in the Ukraine elaborated and approved at state level (December, 2000).

3. The creation of the Ukrainian Research and Academic Network for scientific and educational establishments of the Ukraine to have access to the internet.

\section{TRENDS AND FUTURE ACTIVITY}

Now one of the top priorities in the Ukraine is to the in-service education system, and in-service teacher training in particular. The system of in-service education should be based upon a concept of life-long learning, which is adopted as a strategy in all developed countries in the world.

During market economy development, the role and tasks that the national state, government and administration should fulfill have changed in the Ukraine. With regard to teacher education we can observe a policy of devolution and deregulation. Responsibilities and tasks of the state have been reduced to issues of strategic planning and strategic management. More autonomy has been given to institutions of teacher education. 
At the same time, however, it is maintained that schools and teachers cannot deal adequately with increased, changed and new expectations and tasks:

- Teachers are supposed to acquire competence to establish needed learning environments in order to make high quality education and training outcomes a reality, but teachers do not find ample opportunity to learn the necessary competencies in existing teacher education programmes.

- Teachers should be able to transform academic knowledge into teaching and learning situations in order to make provision of a broad knowledge base. Unfortunately contemporary teacher education does not provide the competencies necessary for these transformation processes.

- Co-operative problem-solving and teamwork seem to be indispensable to meet the challenges of teaching and learning.

Teacher education should be an open and continuously developing system, active to the ever increasing speed of change. The system of teacher training must be able to prepare teachers to meet the task of innovation.

\section{REFERENCES}

Dovgiallo, A., Bykov, V., Kolos, V., Kudrjavtseva, S., Tsybenko, Y. and Vlasenko, N. (1997) WWW - based distance course on the Communication and Information Technologies course (CIT). Proceedings of the Eighth International PEG Conference, Meeting The Challenge of the New Technologies, Sozopol, Bulgaria.

Dovgiallo, A., Kolo, V. and Kudrjavtseva, S. (1998). Ukrainian Experience of Teacher Training on Telematics: Distance Case. Proceedings of the XV IFIP World Computer Congress, Vienna/Austria and Budapest/Hungary.

Kolos, V. (2001). Multimedia distance course development. Proceedings of the International Conference on Telematics and Web-Based Education, Telematica-2001, St.Petersburg, Russia.

\section{BIOGRAPHY}

Valentina Kolos is a senior researcher in the International Research and Training Centre (UNESCO) for Information Technologies and Systems. Her current research is focused mainly on methods for telematic-based distance learning and distance courseware design. 